\title{
EVALUASI KINERJA KARYAWAN OPERATOR BERBASIS PENGEMBANGAN SUMBER DAYA MANUSIA, KOMPENSASI DAN KOMITMEN ORGANISASIONAL
}

\author{
Wiby Ibnu Rahabistara ${ }^{1}$, , Harianto Respati $^{2}$ \\ ${ }^{1}$ Alumni Program Studi Magister Manajemen, Universitas Merdeka Malang, Indonesia \\ ${ }^{2}$ Dosen Fakultas Ekonomi dan Bisnis, Universitas Merdeka Malang, Indonesia
}

\begin{abstract}
This study Aimed to describe the Human Resources Development, Compensation, Organizational Commitment and Employee Performance Operator PT. HM Sampoerna Tbk. Sukorejo Pandaan, analyze the influence of Human Resources Development, Compensation, and Organizational Commitment to Employee Performance Operator PT. HM Sampoerna Tbk. Sukorejo Pandaan, as well as identify and analyze between the variables of Human Resources Development, Compensation, and Organizational Commitment dominant influence on employee performance Operator PT. HM Sampoerna Tbk. Sukorejo Pandaan. The population in this study were employees of the operator PT. HM. Sampoerna Tbk, Sukorejo Pandaan total 670 employees. The number of samples in this study were 250 respondents. The sampling technique used in the study is simple random sampling assuming a homogeneous population. The analysis technique used is multiple regression analysis, $F$ test and test. The analysis showed that the development of human resources, compensation and organizational commitment influence on the performance of employees of PT. HM. Sampoerna Tbk Sukorejo Pandaan, which means that the development of human resources properly implemented, supported with adequate compensation, and high organizational committed employees can improve employee performance. Development of human resources more dominant influence than compensation and organizational commitment to employee performance PT. HM. Sampoerna Tbk Sukorejo Pandaan. This suggests that the main thing to consider to improve the performance of employees of PT. HM. Sampoerna Tbk Sukorejo Pandaan namely human resource development.
\end{abstract}

Keywords: human resource development, compensation, organizational commitment affects employee performance

\section{PENDAHULUAN}

Pengembangan Sumber Daya Manusia merupakan unsur penting dari berbagai upaya perusahaan untuk memenuhi tantangan persaingan global. Pengembangan karyawan merupakan kunci sukses untuk memastikan bahwa para karyawan memiliki berbagai kebutuhan kompetensi. Pengembangan Sumber Daya Manusia adalah suatu proses mengembangkan dan melepaskan keahlian manusia melalui pengembangan organisasi dan pelatihan personil dan pengembangan untuk meningkatkan kinerja (Swanson, 2001:90). Pengembangan karyawan operator penting untuk memastikan dukungan strategi pertumbuhan perusahaan.

Sebagai wujud tanggung jawab pengelolaan sumberdaya manusia, perlu para manajer memperhatikan kualitas kerja dan produktivitas. Salah satu yang harus diperhatikan oleh para manajer adalah bagaimana pelaksanaan program kompensasi pada organisasi. Kompensasi merupakan apa yang diterima oleh para karyawan sebagai ganti kontribusi kerja dalam organisasi (Simamora, 2006:540). Kompensasi ini meliputi seluruh paket keuntungan yang disediakan organisasi kepada para anggotanya dan mekanismemekanisme serta prosedur-prosedur 
dimana keuntungan-keuntungan ini dapat didistribusikan (Sulistyani dan Rosidah, 2003:206).

Program kompensasi ini penting bagi organisasi karena mencerminkan upaya organisasi untuk mempertahankan sumberdaya manusia. Di samping itu, kompensasi merupakan salah satu aspek penting bagi karyawan. Besaran kompensasi mencerminkan ukuran nilai karya di antara karyawan, keluarga dan masyarakat. Bila kompensasi diberikan secara benar, karyawan termotivasi dan dapat fokus pada sasaran-sasaran organisasi.

Kompensasi finansial terdiri atas kompensasi tidak langsung dan langsung. Kompensasi langsung terdiri atas pembayaran karyawan dalam bentuk upah, gaji, bonus, atau komisi. Kompensasi tidak langsung atau benefit terdiri atas semua pembayaran yang tidak tercakup dalam kompensasi finansial langsung yang meliputi liburan, berbagai macam asuransi, jasa seperti perawatan anak atau kepedulian keagamaan, dan sebagainya. Penghargaan non finansial seperti pujian, menghargai diri sendiri, dan pengakuan yang dapat mempengaruhi motivasi kerja karyawan, produktivitas, dan kepuasan (Rivai, 2009:741).

Orang yang berkomitmen pada suatu organisasi atau pada suatu hubungan, maka akan tetap bersama untuk mengarungi rasa suka maupun duka demi tercapainya tujuan bersama. Commitment in a relationship (komitmen dalam suatu hubungan) yang berarti bahwa semua kekuatan positif dan negatif yang menjaga individu akan tetap berada dalam suatu hubungan. Terdapat tiga faktor utama yang mempengaruhi komitmen di dalam suatu hubungan, yang pertama komitmen dipengaruhi oleh kekuatan daya tarik pada partner atau hubungan tertentu. Yang kedua, komitmen dipengaruhi oleh nilai dan prinsip moral pada diri individu, dan yang ketiga, komitmen didasarkan pada kekuatan negatif atau penghalang yang menyebabkan seseorang merasa rugi besar jika harus meninggalkan suatu hubungan (Taylor et al., 2009:350-351).

Karyawan yang memiliki komitmen, mempunyai keinginan untuk memberikan tenaga, pikiran serta tanggung jawab lebih untuk meningkatkan kesejahteraan dan keberhasilan organisasi. Keberhasilan organisasi bergantung pada peran karyawan yang terlibat. Komitmen berdampak pada tingkat produktivitas dan kualitas kerja. Terdapat beberapa tujuan dari organisasi, yang pertama yaitu dapat berupa perbaikan dari pelayanan pelanggan, sehingga pelanggan akan merasa puas dengan apa yang didapatnya. Yang kedua yaitu dapat memenuhi permintaan pasar, dan yang ketiga organisasi harus dapat meningkatkan suatu kinerja (Wibowo, 2011: 9-10).

Setiap organisasi mengharapkan suatu keberhasilan, untuk mencapai keberhasilan tersebut membutuhkan adanya karyawan yang berkualitas. Untuk menciptakan karyawan yang berkualitas, dibutuhkan suatu dorongan kuat dari seorang manajer. Dorongan tersebut dapat berupa pemberian motivasi kepada karyawan, bertujuan untuk meningkatkan kinerja karyawan. Selain motivasi, diperlukan komitmen organisasi untuk pencapaian kinerja karyawan. Karyawan yang memiliki motivasi dan komitmen yang tinggi maka karyawan akan bekerja seoptimal mungkin sehingga hasil kerja yang diperoleh akan meningkat.

Beberapa penelitian mengenai pengembangan sumber daya manusia, kompensasi dan komitmen, di antaranya Kuniawan (2010) dan Limgiani (2013) membuktikan bahwa kompetensi pengembangan sumber daya manusia berpengaruh signifikan terhadap kinerja. Lestariningsih et al. (2012) dan Supiyanto (2015) menyatakan bahwa kompensasi berpengaruh terhadap kinerja. Lestariningsih et al. (2012), Limgiani (2013), Supiyanto (2015) membuktikan bahwa komitmen berpengaruh terhadap kinerja. 
Uraian diatas menjelaskan bahwa pengembangan kualitas sumber daya manusia mempunyai posisi yang sangat dibutuhkan organisasi. Untuk itu perlu ada strategi untuk meningkatkan kualitas sumber daya manusia, yang mengarah pada pembangunan sumber daya manusia yang utuh baik pembangunan bidang jasmani maupun rohani. Kompensasi sebagai salah satu yang dapat meningkatkan kinerja karyawan, karena pandangan-pandangan karyawan mengenai uang atau imbalan langsung nampaknya sangat subjektif dan merupakan sesuatu yang sangat khas dalam industri. Komitmen pada setiap karyawan sangat penting karena dengan suatu komitmen seorang karyawan dapat menjadi lebih bertanggung jawab terhadap pekerjaannya dibanding dengan karyawan yang tidak mempunyai komitmen. Karyawan yang memiliki komitmen, akan bekerja secara optimal sehingga dapat mencurahkan perhatian, pikiran, tenaga dan waktunya untuk pekerjaan. Penjelasan ini menjadikan dasar untuk untuk melakukan penelitian tentang dampak pengembangan sumber daya manusia, kompensasi dan komitmen organisasional terhadap kinerja karyawan PT. HM Sampoerna, Tbk. Sukorejo Pandaan.

\section{TINJAUAN PUSTAKA}

\section{Teori Kinerja}

Setiap manusia mempunyai potensi untuk bertindak dalam berbagai bentuk aktivitas. Kemampuan bertindak itu dapat diperoleh manusia secara alami (ada sejak lahir) atau dipelajari. Walaupun manusia mempunyai potensi untuk berperilaku tertentu tetapi perilaku itu hanya diaktualisasi pada saat-saat tertentu saja. Potensi untuk berperilaku tertentu itu disebut ability (kemampuan), sedangkan ekspresi dari potensi ini dikenal sebagai performance (kinerja). Selanjutnya menurut Mangkunegara (2009:67), "Istilah kinerja berasal dari kata Job Performance atau Actual Performance (prestasi kerja atau prestasi sesungguhnya yang dicapai oleh seseorang). Pengertian kinerja (prestasi kerja) adalah hasil kerja secara kualitas dan kuantitas yang dicapai oleh seorang pegawai dalam melaksanakan tugasnya sesuai dengan tanggung jawab yang diberikan kepadanya". Sedangkan Timpe (2002) menyatakan bahwa kinerja adalah tingkat prestasi seseorang atau karyawan dalam suatu organisasi atau perusahaan yang dapat meningkatkan produktivitas.

Menurut Dharma (2005:32), standar pengukuran kinerja diantaranya sebagai berikut :

1) Kuantitas, yaitu jumlah yang harus diselesaikan atau dicapai. Pengukuran kuantitatif melibatkan perhitungan keluaran dari proses atau pelaksanaan kegiatan. Ini berkaitan dengan jumlah keluaran yang dihasilkan.

2) Kualitas, yaitu mutu yang harus dihasilkan (baik tidaknya). Pengukuran kualitatif keluaran mencerminkan pengukuran "tingkat kepuasan," yaitu seberapa baik penyelesaiannya. Ini berkaitan dengan bentuk keluaran.

3) Ketepatan Waktu, yaitu sesuai tindaknya dengan waktu yang direncanakan. Pengukuran ketepatan waktu merupakan jenis khusus dari pengukuran kuantitatif yang menentukan ketepatan waktu penyelesaian suatu kegiatan.

\section{Teori Pengembangan Sumber Daya Manusia (SDM)}

Pengembangan sumber daya manusia menurut Magginson et al. (2002:6) adalah sebagai berikut : "Istilah yang digunakan untuk menjelaskan pendekatan yang terintregasi dan holistik untuk mengubah perilaku kerja dengan menggunakan teknik dan strategik belajar". Sedangkan pengembangan sumber daya manusia menurut Nursiah (2011:21) adalah "kegiatan yang harus dilakukan oleh perusahaan, agar pengetahuan, kemampuan, dan ketrampilan mereka sesuai dengan tuntutan 
pekerjaan yang mereka lakukan.” Selanjutnya Mondy dan Noe (2006:270) menyatakan pengembangan sumber daya manusia adalah suatu usaha yang terencana dan berkelanjutan yang dilakukan oleh organisasi dalam meningkatkan kompetensi pegawai dan kinerja organisasi melalui programprogram pelatihan, pendidikan, dan pengembangan.

\section{Teori Kompensasi}

Hasibuan (2008:118), kompensasi didefinisikan sebagai semua pendapatan yang berbentuk uang, barang langsung atau tidak langsung yang diterima karyawan sebagai imbalan atau jasa yang telah diberikan pada perusahaan. Lebih lanjut menurut Simamora (2006:442) kompensasi didefinisikan sebagai apa yang diterima oleh para karyawan sebagai ganti kontribusi mereka kepada organisasi. Selanjutnya Handoko (2008:155) mendefinisikan kompensasi sebagai segala sesuatu yang diterima para karyawan sebagai balas jasa untuk kerja mereka.

Menurut Simamora (2006:442) komponen-komponen kompensasi terbagi dalam bentuk Kompensasi Langsung (direct compensation) dan komponen tidak langsung (indirect compensation). Kompensasi finansial langsung (direct financial compensation) terdiri dari bayaran (pay) yang diperoleh seseorang dalam bentuk gaji, upah, bonus dan komisi. Kompensasi finansial tidak langsung (indirect financial compensation), yang disebut juga dengan tunjangan, meliputi semua imbalan finansial yang tidak tercakup dalam kompensasi langsung. Kompensasi non finansial (non financial compensation) terdiri atas kepuasan yang diperoleh seseorang dari pekerjaan itu sendiri, atau dari lingkungan psikologis dan/ fisik dimana orang itu bekerja.

\section{Teori Komitmen Organisasional}

Menurut Mathis dan Jackson (2000) dalam Sopiah (2008:155) memberikan definisi bahwa, "Organizational Commitment is the degree to which employees believe in and accept organizational goals and desire to remain with the organization". (Komitmen organisasional adalah derajat yang mana karyawan percaya dan menerima tujuantujuan organisasi dan akan tetap tinggal atau tidak akan meninggalkan organisasi). Robbins (1989) dalam Sopiah (2008:155156) mendefinisikan, "Komitmen organisasional sebagai suatu sikap yang merefleksikan perasaan suka atau tidak suka dari karyawan terhadap organisasi”. Lincoln (1989) dan Bashaw (1994) dalam Sopiah (2008:156) mengemukakan bahwa, "Komitmen organisasional memiliki tiga indikator : kemauan karyawan, kesetiaan karyawan dan kebanggaan karyawan pada organisasi”.

Dalam Sopiah (2008:157-158), Meyer, Allen, dan Smith mengemukakan bahwa ada tiga komponen komitmen organisasional, yaitu :

1) Affective commitment, terjadi apabila karyawan ingin menjadi bagian dari organisasi karena adanya ikatan emosional.

2) Continuance commitment, muncul apabila karyawan tetap bertahan pada suatu organisasi karena membutuhkan gaji dan keuntungan-keuntungan lain, atau karena karyawan tersebut tidak menemukan pekerjaan lain.

Normative commitment, timbul dari nilainilai dalam diri karyawan. Karyawan bertahan menjadi anggota organisasi karena adanya kesadaran bahwa komitmen terhadap organisasi merupakan hal yang seharusnya dilakukan.

Berdasarkan pada hasil penelitian terdahulu, sebagaimana nama peneliti terhdahulu nampak pada garis panah pada Gambar 1, maka kerangka konsep penelitian digambarkan di bawah ini. 


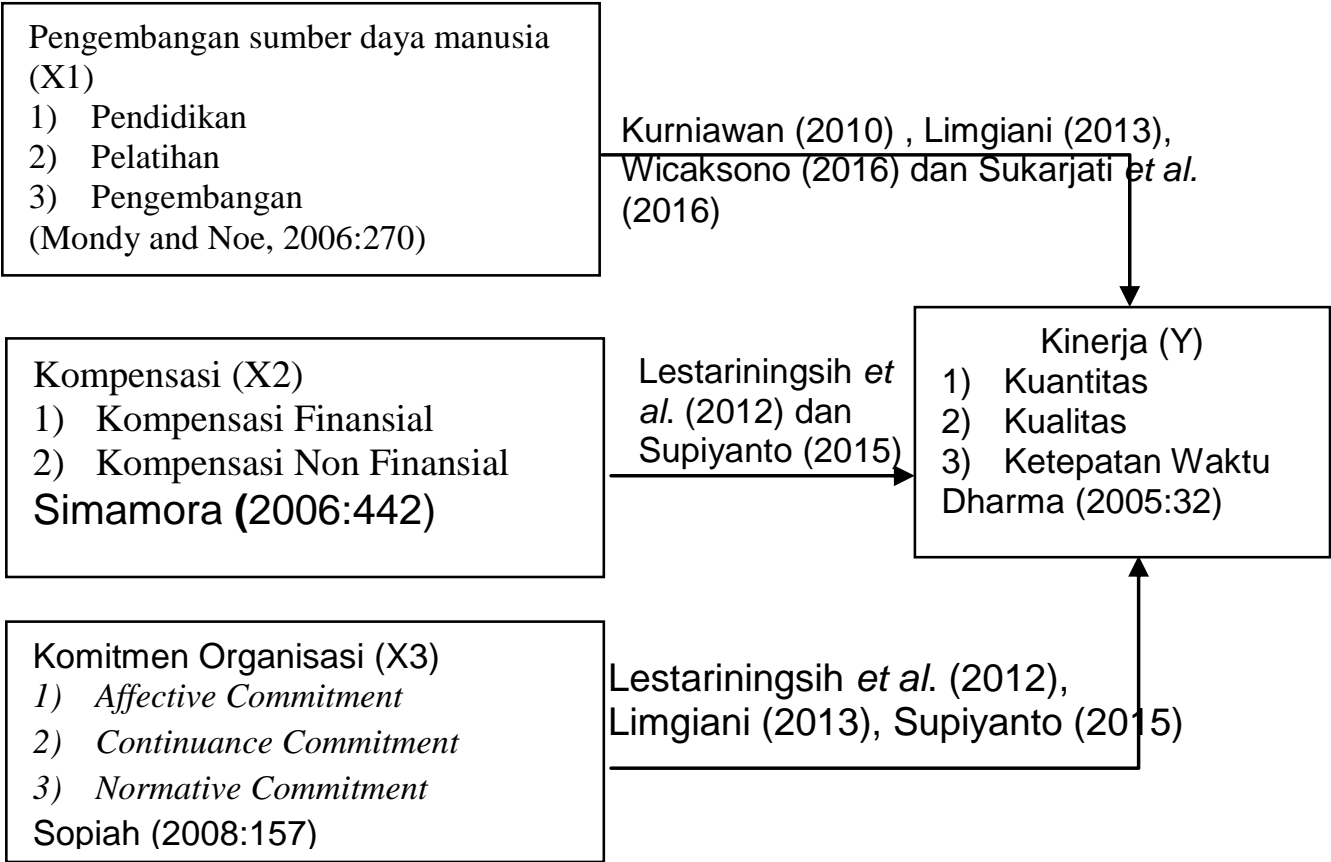

\section{Gambar I \\ Hipotesis \\ Berdasarkan landasan teori dan kerangka konseptual yang telah \\ dilanjutkan dengan operasionalisasi konsep, sampai penyimpulan sebagai suatu temuan penelitian.} dipaparkan, maka dapat disusun hipotesis penelitian sebagai berikut :

H1: Pengembangan Sumber Daya Manusia, Kompensasi dan Komitmen organisasional berpengaruh signifikan terhadap Kinerja Karyawan Operator .

H2: Pengembangan Sumber Daya Manusia berpengaruh dominan terhadap Kinerja Karyawan Operator.

\section{METODE PENELITIAN Rancangan Penelitian}

Berdasarkan tujuan penelitian ini, maka desain penelitian adalah desain penelitian kausalitas. Menurut Sanusi (2014:14) desain kausalitas adalah desain penelitian yang disusun untuk meneliti kemungkinan hubungan sebab-akibat antar variabel. Pendekatan penelitian ini adalah menjelaskan hubungan sebab akibat yang sudah diprediksi oleh peneliti. Desain penelitian penelitian ini adalah kuantitatif, yang prosesnya diawali dengan penyusunan model teoritis dan analisis sebagai dasar pengajuan pernyataan sementara (hipotesis), kemudian

\section{Variabel Penelitian}

\section{Identifikasi Variabel}

a. Variabel bebas (X)

1) Pengembangan sumber daya manusia $\left(\mathrm{X}_{1}\right)$

2) Kompensasi $\left(X_{2}\right)$

3) Komitmen organisasional $\left(X_{3}\right)$

b. Variabel terikat (Y)

Variabel terikat dalam penelitian ini adalah kinerja (Y)

\section{Definisi Konseptual Variabel Penelitian}

a. Pengembangan sumber daya manusia Mondy dan Noe (2006:270) menyatakan pengembangan sumber daya manusia adalah suatu usaha yang terencana dan berkelanjutan yang dilakukan oleh organisasi dalam meningkatkan kompetensi pegawai dan kinerja organisasi melalui program-program pelatihan, pendidikan, dan pengembangan.

b. Kompensasi

Kompensasi menurut Hasibuan (2008:118) adalah sebagai semua 
pendapatan yang berbentuk uang, barang langsung atau tidak langsung yang diterima karyawan sebagai imbalan atau jasa yang telah diberikan pada perusahaan. Komitmen Organisasi Komitmen menurut Sunarto (2005:17) adalah "kecintaan dan kesetiaan yang terdiri dari : (1) Penyatuan dengan tujuan dan nilai-nilai perusahaan, (2) Keinginan untuk tetap berada dalam organisasi, dan (3) Kesediaan untuk bekerja keras atas nama organisasi."Kinerja Mangkunegara (2009:67) mendefinisikan kinerja adalah hasil kerja secara kualitas dan kuantitas yang dicapai oleh seorang pegawai dalam melaksanakan tugasnya sesuai dengan tanggung jawab yang diberikan kepadanya. Definisi Operasional Variabel Penelitian Pengembangan sumber daya manusia Pengembangan sumber daya manusia merupakan pengembangan fisik maupun mental, melaluiprogrampeningkatan daya pikir dengan dunia pendidikan dan didukung dengan program pelatihan sebagai bahan praktek setelah mendapatkan ilmu secara teoritis. Indikator yang digunakan dalam penelitian ini sebagai berikut : Pendidikan

Pelatihan Pengembangan

c. Kompensasi

Kompensasi merupakan apa yang diterima oleh karyawan dari perusahaan sebagai balas jasa atas kerja mereka baik yang langsung berupa uang (finansial) maupun yang tidak langsung berupa uang (non finansial).

Indikator yang digunakan yaitu :

1) Kompensasi finansial

2) Kompensasi non financial

d. Komitmen Organisasional

Komitmen organisasional merupakan suatu kesetiaan yang dimiliki oleh seorang karyawan untuk tetap bertahan dalam keadaan suka maupun duka di dalam suatu perusahaan. Indikator yang digunakan adalah sebagai berikut : Affective Commitment, Continuance Commitment, dan Normative Commitment

e. Kinerja

Kinerja karyawan merupakan suatu hasil kerja yang telah dicapai oleh seorang karyawan di dalam melaksanakan suatu pekerjaan yang telah diberikan kepadanya untuk mencapai tujuan dari organisasi, yang diukur dengan indikator sebagai berikut : Kuantitas, Kualitas dan Ketepatan Waktu.

\section{Populasi dan Teknik Pengambilan Sampel}

\section{Populasi}

Populasi dalam penelitian ini adalah karyawan operator PT. HM. Sampoerna Tbk, Sukorejo Pandaan yang berjumlah 670 karyawan.

\section{Sampel}

Dari berbagai rumus yang ada, dalam Metode Penelitian Kuantitatif, ada sebuah rumus untuk menentukan besaran jumlah sampel, yaitu menggunakan Rumus Slovin :

$\mathbf{n}=\frac{N}{1+N e^{2}}$

Keterangan :

$\mathrm{n}$ = besaran sampel

$\mathrm{N}=$ besaran populasi

$\mathrm{e}=$ nilai kritis (batas ketelitian) yang dinginkan (persen kelonggaran ketidak telitian karena kesalahan penarikan sampel).

$$
\begin{aligned}
& \mathrm{n}=\frac{670}{1+670(0,05)^{2}} \\
& \mathrm{n}=\frac{670}{2,675}=250
\end{aligned}
$$

Jadi jumlah sampel dalam penelitian ini sebanyak 250 responden.

Teknik pengambilan sampel yang digunakan dalam penelitian yaitu simple random sampling dengan 
asumsi populasi bersifat homogen. Simple random sampling adalah suatu tipe sampling probabilitas, di mana peneliti dalam memilih sampel dengan memberikan kesempatan yang sama kepada semua anggota populasi untuk ditetapkan sebagai anggota sampel.

\section{Teknik Analisis Data}

1. Analisis Deskriptif

Analisis deskriptif dalam penelitian ini akan digunakan untuk mengetahui distribusi frekuensi jawaban responden atas hasil pengumpulan kuesioner yang dilakukan. Analisis ini diperlukan untuk mendeskriptifkan atau menggambarkan data hasil pengumpulan kuesioner. Teknik yang digunakan untuk menggambarkan data lapangan secara deskriptif dengan cara menginterpretasikan hasil pengolahan data lewat tabulasi. Teknik ini diharapkan dapat mendukung interpretasi hasil analisis yang digunakan.

2. Analisis Regresi Linear Berganda Analisis Regresi Linear Berganda digunakan untuk mengetahui pengaruh Pengembangan Sumber Daya Manusia, Kompensasi dan Komitmen Organisasional terhadap Kinerja PT. HM. Sampoerna, Tbk, Sukorejo Pandaan, digunakan regresi linier berganda dengan bantuan program SPSS dengan persamaan :

$$
\begin{array}{cl}
\mathbf{Y}=\mathbf{a}+\boldsymbol{\beta}_{\mathbf{1}} \mathbf{X}_{\mathbf{1}}+\boldsymbol{\beta}_{\mathbf{2}} \mathbf{X}_{\mathbf{2}}+\boldsymbol{\beta}_{\mathbf{3}} \mathbf{X}_{\mathbf{3}}+\mathbf{e} \\
\text { Keterangan : } \\
\mathrm{Y} \quad=\text { Kinerja Pegawai } \\
\mathrm{a} & =\text { bilangan konstanta } \\
\beta_{1 . .} \beta_{3} & =\text { koefisien regresi } \\
\mathrm{X}_{1} & =\text { Pengembangan sumber daya } \\
& \text { manusia } \\
\mathrm{X}_{2} & =\text { Kompensasi } \\
\mathrm{X}_{3} & =\text { Komitmen organisasional } \\
\mathrm{e} & =\text { variabel pengganggu }
\end{array}
$$

\section{HASIL DAN PEMBAHASAN}

Hasil

\section{Uji Asumsi Klasik}

Guna memperoleh nilai penduga yang tidak bias dan efisien dari suatu persamaan regresi berganda dengan metode kuadrat terkecil biasa (Ordinary Least Square), maka dalam pelaksanaan analisis data harus memenuhi asumsi klasik sebagai berikut :

a. Multikolinieritas

Suatu model regresi terbebas dari multikolinieritas jika nilai VIF (Variance Inflation Factors) dari masing-masing variabel independen kurang dari 5 dan nilai toleransi mendekati 1. Adapun hasil VIF disajikan pada tabel berikut :

Tabel 1

Hasil Uji Multikolinieritas

\begin{tabular}{|c|l|c|c|}
\hline \multirow{2}{*}{\multicolumn{2}{|l|}{ Model }} & \multicolumn{2}{|c|}{ Collinearity Statistics } \\
\cline { 3 - 4 } & Tolerance & VIF \\
\hline 1 & Pengembangan sumber daya manusia & 0,652 & 1,553 \\
\hline 2 & Kompensasi & 0,680 & 1,471 \\
\hline 3 & Komitmen organisasional & 0,775 & 1,290 \\
\hline
\end{tabular}

Berdasarkan hasil perhitungan VIF terlihat bahwa variabel pengembangan sumber daya manusia, kompensasi mempunyai nilai VIF $<5$, dengan demikian dapat disimpulkan model regresi tersebut tidak terdapat problem multikolinieritas. 
b. Heteroskedastisitas

Heteroskedastisitas berarti adanya variasi residual yang tidak sama untuk semua pengamatan, atau terdapatnya variasi residual yang semakin besar pada jumlah pengamatan yang semakin besar. Pengujian gejala heterokedastisitas menggunakan scatterplot, hasil uji heteroskedastisitas disajikan pada Gambar 2 berikut :

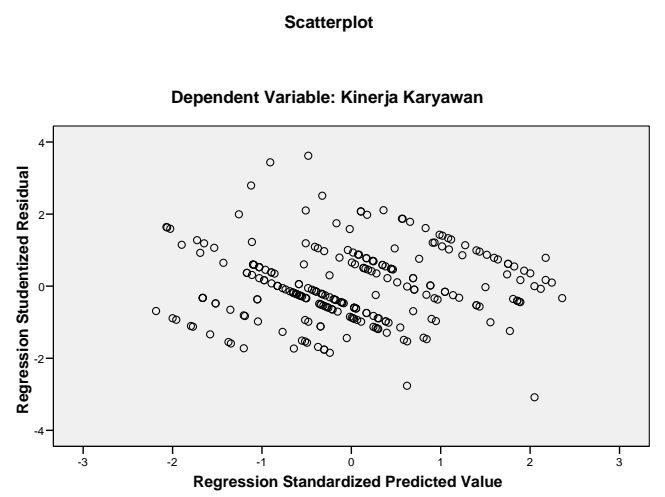

Berdasarkan Gambar 2, terlihat titiktitik menyebar secara acak, tidak membentuk sebuah pola tertentu yang jelas, serta tersebar baik di atas maupun di bawah angka 0 pada sumbu Y. Hal ini berarti tidak terjadi heteroskedastisitas pada model regresi.

c. Normalitas

Asumsi data telah berdistribusi normal adalah salah satu asumsi yang penting dalam melakukan penelitian dengan regresi. Uji ini bertujuan untuk menguji apakah dalam model regresi, variabel independen, dependen dan moderasi terdistribusi secara normal atau tidak. Ghozali (2006) untuk mendeteksi normalitas data dapat dilakukan dengan melihat penyebaran data (titik-titik pada sumbu diagonal dari grafik, yaitu jika data menyebar di sekitar garis diagonal dan mengikuti arah garsi diagonal tersebut, maka hal ini menunjukkan data yang telah terdistribusi normal.

Normal P-P Plot of Regression Standardized Residual

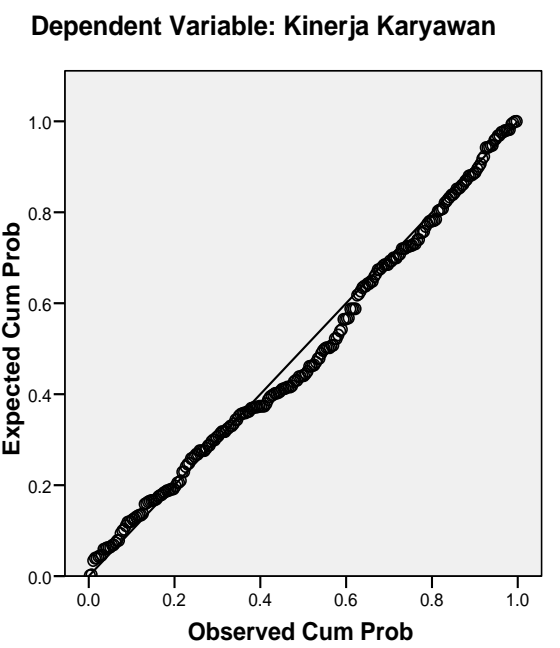

Gambar 3 menunjukkan bahwa data (titik) menyebar di sekitar dan mendekati garis diagonal. Ini menunjukkan bahwa data penelitian yang mencakup variabel pengembangan sumber daya manusia, kompensasi dan komitmen organisasional berdistribusi normal.

\section{Analisis Regresi Linear Berganda}

Dari hasil pengolahan data dengan menggunakan bantuan komputer program SPSS 15 for windows diperoleh hasil analisis seperti dalam tabel berikut : 
Tabel 2

Rekapitulasi Hasil Analisis Regresi Linier Berganda

\begin{tabular}{|c|c|c|c|c|}
\hline Variabel & $\begin{array}{l}\text { Koefisien } \\
\text { Regresi }\end{array}$ & $t_{\text {hitung }}$ & Sig. & Keterangan \\
\hline $\begin{array}{l}\text { Pengembangan sumber } \\
\text { daya manusia }\left(X_{1}\right)\end{array}$ & 0,565 & 10,546 & 0,000 & Signifikan \\
\hline Kompensasi $\left(\mathrm{X}_{2}\right)$ & 0,167 & 2,961 & 0,003 & Signifikan \\
\hline $\begin{array}{l}\text { Komitmen organisasional } \\
\left(X_{3}\right)\end{array}$ & 0,120 & 2,257 & 0,025 & Signifikan \\
\hline Konstanta & 0,563 & & & \\
\hline $\mathbf{R}$ & 0,728 & & & \\
\hline Adjusted $R$ square & 0,524 & & & \\
\hline F hitung & 92,214 & & & \\
\hline Sig. F & 0,000 & & & \\
\hline $\mathrm{n}$ & 250 & & & \\
\hline \multicolumn{5}{|c|}{ Variabel terikat = Kinerja karyawan (Y) } \\
\hline $\begin{array}{l}\mathrm{F} \text { tabel }=2,60 \\
\mathrm{t} \text { tabel }=1,960\end{array}$ & & & & \\
\hline
\end{tabular}

Berdasarkan tabel rekapitulasi tersebut, maka diperoleh persamaan regresi berganda sebagai berikut :

$Y=0,563+0,565 X_{1}+0,167 X_{2}+0,120 X_{3}$

Berdasarkan persamaan tersebut dapat dijelaskan sebagai berikut :

$\mathrm{a}=0,563$ adalah konstanta yang artinya bahwa apabila semua variabel bebas pengembangan sumber daya manusia $\left(\mathrm{X}_{1}\right)$, kompensasi $\left(\mathrm{X}_{2}\right), \quad$ dan komitmen organisasional $\left(\mathrm{X}_{3}\right)$ adalah 0 , maka besarnya variabel kinerja karyawan sebesar 0,563.

$\mathrm{b}_{1}=0,565$ adalah besarnya koefisien regresi variabel bebas pengembangan sumber daya manusia $\left(X_{1}\right)$, koefisien regresi bertanda positif menunjukkan pengembangan sumber daya manusia berpengaruh searah terhadap kinerja karyawan, artinya semakin baik pengembangan sumber daya manusia akan menyebabkan kinerja karyawan mengalami peningkatan, dengan anggapan variabel kompensasi $\left(\mathrm{X}_{2}\right)$ dan komitmen organisasional $\left(\mathrm{X}_{3}\right)$ besarnya tetap. Sedangkan pengaruh pengembangan sumber daya manusia terhadap kinerja karyawan sebesar 0,565 .

$b_{2}=0,167$ adalah besarnya koefisien regresi variabel bebas kompensasi
$\left(\mathrm{X}_{2}\right)$, koefisien regresi bertanda positif menunjukkan kompensasi berpengaruh searah terhadap kinerja karyawan, artinya semakin baik kompensasi akan menyebabkan kinerja karyawan semakin meningkat dengan anggapan variabel pengembangan sumber daya manusia $\left(\mathrm{X}_{1}\right)$, dan komitmen organisasional $\left(\mathrm{X}_{3}\right)$ besarnya tetap. Sedangkan pengaruh kompensasi terhadap kinerja karyawan sebesar 0,167.

$\mathrm{b}_{3}=0,120$ adalah besarnya koefisien regresi variabel bebas komitmen organisasional $\left(\mathrm{X}_{3}\right)$, koefisien regresi bertanda positif menunjukkan komitmen organisasional berpengaruh searah terhadap kinerja karyawan, artinya semakin baik komitmen organisasional akan menyebabkan kinerja karyawan mengalami peningkatan, dengan anggapan variabel pengembangan sumber daya manusia $\left(\mathrm{X}_{1}\right)$ dan kompensasi $\left(\mathrm{X}_{2}\right)$ besarnya tetap. Sedangkan pengaruh komitmen organisasional terhadap kinerja karyawan sebesar 0,120.

Nilai koefisien korelasi berganda (R) sebesar 0,728 menunjukkan adanya hubungan yang kuat antara pengembangan sumber daya manusia $\left(\mathrm{X}_{1}\right)$, kompensasi 
$\left(\mathrm{X}_{2}\right)$, dan komitmen organisasional $\left(\mathrm{X}_{3}\right)$ secara bersama-sama dengan kinerja

karyawan (Y).

Dari hasil perhitungan regresi berganda di atas, dapat diketahui nilai koefisien determinasi (Adjusted $R$ square) sebesar 0,524. Koefisien determinasi ini mempunyai arti bahwa pengembangan sumber daya manusia $\left(\mathrm{X}_{1}\right)$, kompensasi $\left(\mathrm{X}_{2}\right)$, dan komitmen organisasional $\left(\mathrm{X}_{3}\right)$ secara bersama-sama mampu memberikan kontribusi terhadap kinerja karyawan sebesar $52,4 \%$, sedangkan sisanya sebesar $47,6 \%$ disebabkan oleh variabel lain yang tidak dimasukkan dalam penelitian.

\section{Uji Hipotesis}

a. Pengujian Hipotesis Pertama

Untuk menguji hipotesis pertama yang menyatakan bahwa Pengembangan Sumber Daya Manusia, Kompensasi dan Komitmen organisasional berpengaruh signifikan terhadap Kinerja Karyawan Operator PT. HM. Sampoerna, Tbk, Sukorejo Pandaan, dengan menggunakan uji F. Dari hasil perhitungan analisis regresi berganda dengan SPSS diperoleh $\mathrm{F}_{\text {hitung }}$ sebesar 92,214 , sedangkan $\mathrm{F}_{\text {tabel }}$ pada $\alpha=5 \%, \mathrm{df}_{1}=3$, dan $\mathrm{df}_{2}=246$ sebesar 2,60; hal ini berarti $\mathrm{F}_{\text {hitung }}>$
$\mathrm{F}_{\text {tabel }}(92,214>2,60)$ sedangkan nilai probabilitasnya lebih kecil dari $\alpha=$ $0,05(0,000<0,05)$, maka Ho ditolak dan Ha diterima yang berarti bahwa variabel bebas : Pengembangan sumber daya manusia, Kompensasi dan Komitmen organisasional secara simultan berpengaruh sangat signifikan terhadap kinerja karyawan. Dengan demikian hipotesis pertama secara statistik dapat diterima atau teruji.

b. Pengujian Hipotesis Kedua

Untuk menguji hipotesis kedua yang menyatakan Pengembangan Sumber Daya Manusia mempunyai pengaruh yang dominan terhadap Kinerja Karyawan Operator PT. HM. Sampoerna, Tbk, Sukorejo Pandaan, dengan menggunakan uji t. Uji t digunakan untuk menguji apakah masing-masing variabel bebas Pengembangan sumber daya manusia, Kompensasi dan Komitmen organisasional secara parsial berpengaruh signifikan terhadap kinerja karyawan, dengan cara membandingkan antara $t_{\text {hitung }}$ dengan $t_{\text {tabel. }}$. Hasil perhitungan $t_{\text {hitung }}$ dan $t_{\text {tabel }}$ masing-masing variabel bebas adalah sebagai berikut :

Tabel 3

Perbandingan $t_{\text {hitung }}$ dan $t_{\text {tabel }} \alpha=5 \%$

\begin{tabular}{|lc|c|c|c|}
\hline \multicolumn{1}{|c|}{ Variabel } & $t_{\text {hitung }}$ & ttabel & Sig. & Keterangan \\
\hline Pengembangan sumber daya manusia $\left(X_{1}\right)$ & 10,546 & 1,960 & 0,000 & Signifikan \\
\hline Kompensasi $\left(X_{2}\right)$ & 2,961 & 1,960 & 0,003 & Signifikan \\
\hline Komitmen organisasional $\left(X_{3}\right)$ & 2,257 & 1,960 & 0,025 & Signifikan \\
\hline
\end{tabular}

ditolak atau Ha diterima, dan terbukti

Dari tabel di atas dapat dijelaskan sebagai berikut :

1) Variabel pengembangan sumber daya manusia (X1)

Hasil analisis regresi diperoleh nilai $\mathrm{t}_{\text {hitung }}=10,546$ sedangkan nilai $\mathrm{t}_{\text {tabel }}=$ 1,960 sehingga $t_{\text {hitung }}>t_{\text {tabel }}$ atau nilai signifikansi $0,000<0,05$ jadi Ho variabel pengembangan sumber daya manusia (X1) berpengaruh signifikan terhadap kinerja karyawan (Y).

2) Variabel kompensasi (X2)

Hasil analisis regresi diperoleh nilai $t_{\text {hitung }}=2,961$ sedangkan nilai $t_{\text {tabel }}=$ 
1,960 sehingga $t_{\text {hitung }}>t_{\text {tabel }}$ atau nilai signifikansi $0,003<0,05$ jadi Ho ditolak atau Ha diterima, dan terbukti variabel kompensasi (X2) berpengaruh signifikan terhadap kinerja karyawan (Y).

3) Variabel komitmen organisasional (X3) Hasil analisis regresi diperoleh nilai $t_{\text {hitung }}=2,257$ sedangkan nilai $t_{\text {tabel }}=$ 1,960 sehingga $t_{\text {hitung }}>t_{\text {tabel }}$ atau nilai signifikansi $0,025<0,05$ jadi Ho ditolak atau Ha diterima, dan terbukti variabel komitmen organisasional (X3) berpengaruh signifikan terhadap kinerja karyawan (Y).

Berdasarkan hasil uji t tersebut di atas, maka dapat dibuktikan bahwa Pengembangan sumber daya manusia, Kompensasi dan Komitmen organisasional secara parsial berpengaruh signifikan terhadap kinerja karyawan (Y). Sedangkan untuk mengetahui variabel yang berpengaruh dominan dengan dengan melihat besarnya koefisien regresi yang berpengaruh signifikan terhadap kinerja karyawan. Variabel bebas yang memiliki koefisien paling besar dan signifikan merupakan variabel yang berpengaruh dominan terhadap kinerja karyawan. Berdasarkan hasil analisis regresi berganda dapat diketahui bahwa nilai koefisien regresi terbesar yaitu pengembangan sumber daya manusia sebesar 0,571 , hal ini berarti pengembangan sumber daya manusia merupakan variabel yang berpengaruh dominan terhadap kinerja karyawan. Berikutnya adalah kompensasi yaitu sebesar 0,157, kemudian variabel komitmen organisasional yaitu sebesar 0,112. Dengan demikian hipotesis kedua secara statistik dapat diterima atau teruji.

\section{Pembahasan}

a. Pengembangan Sumber Daya Manusia Pengembangan sumber daya manusia dibentuk oleh pelatihan, pendidikan dan pengembangan, dengan kontribusi terbesar yaitu pelatihan. Pelatihan dicerminkan dari pelatihan-pelatihan yang pernah diikuti sudah sesuai dengan kebutuhan jabatan saat ini dan pelatihan-pelatihan yang diikuti bisa meningkatkan ketrampilan dalam pengambilan keputusan. Pelatihan karyawan dilakukan dengan tujuan agar para karyawan memiliki pengetahuan, kemampuan dan keterampilan sesuai dengan tuntutan pekerjaan yang karyawan lakukan. Pelatihan karyawan yang tepat, dapat memberikan efek yang baik kepada karyawan sehingga karyawan dapat mengembangkan diri dan mampu memahami beberapa hal terkait pekerjaannya, antara lain: memahami seluk beluk pelaksanaan pekerjaan lebih mendalam, dapat memahami perkembangan perusahaan, dapat memahami sasaran yang akan dicapai perusahaan, mengerti akan perlunya kerjasama dalam melaksanakan pekerjaan, dapat mudah memahami Informasi yang disampaikan perusahaan, dapat memahami setiap kesulitan-kesulitan yang dihadapi perusahaan, mampu melakukan hubungan-hubungan dengan lingkungan, mampu memahami kebijaksanaan dan peraturan yang berlaku dalam perusahaan, mampu memahami sistem dan prosedur yang digunakan dalam pelaksanaan tugas perusahaan, mampu memahami dan menerapkan perilaku yang mendukung dan dituntut perusahaan. Hal ini sesuai dengan pendapat Nursiah (2011:21) bahwa pengembangan sumber daya manusia adalah kegiatan yang harus dilakukan oleh perusahaan, agar pengetahuan, kemampuan, dan ketrampilan mereka sesuai dengan tuntutan pekerjaan yang mereka lakukan.

b. Kompensasi

Kompensasi dibentuk oleh kompensasi finansial dan kompensasi non finansial. Kompensasi finansial dan kompensasi non finansial penting bagi karyawan, 
kompensasi finansial dicerminkan dari kesesuaian gaji dengan yang diharapkan, pimpinan memberikan bonus bagi karyawan yang berprestasi dan perusahaan memberikan tunjangan dengan ketentuan perusahaan. Sedangkan kompensasi non finansial dicerminkan dari diberikan kesempatan untuk meningkatkan jenjang karir, mendapat penghargaaan (Reward) atas prestasi pekerjaan dan memperoleh fasilitas sesuai dengan jabatan dalam pekerjaan. Pentingnya kompensasi sebagai imbalan langsung nampaknya sangat subyektif dan barangkali merupakan sesuatu yang sangat khas dalam perusahaan. Sebagaimana pendapat Handoko (2008:155) mendefinisikan kompensasi sebagai segala sesuatu yang diterima para karyawan sebagai balas jasa untuk kerja karyawan. Kompensasi penting bagi karyawan sebagai individu karena besarnya kompensasi mencerminkan ukuran nilai karya karyawan di antara karyawan itu sendiri, keluarga dan masyarakat. Kemudian program kompensasi juga penting bagi perusahaan, karena hal itu mencerminkan upaya organisasi untuk mempertahankan sumber daya manusia yang dimiliki perusahaan.

c. Komitmen Organisasional

Komitmen organisasional dibentuk oleh Affective Commitment, Continuance Commitment dan Normative Commitment, dengan kontribusi terbesar adalah Affective Commitment. Affective Commitment dicerminkan dari senang bisa menghabiskan sisa karir di perusahaan, bangga menjadi anggota dari perusahaan dan mempunyai keinginan untuk tetap tinggal di perusahaan. Komitmen Affective Commitment menyebabkan karyawan bertahan pada suatu pekerjaan karena karyawan menginginkannya. Sebagaimana konsepsi komitmen organisasional menurut Robbins (1989) dalam Sopiah (2008:155-156) adalah "Komitmen organisasional sebagai suatu sikap yang merefleksikan perasaan suka atau tidak suka dari karyawan terhadap organisasi”. Sedangkan indikator komitmen organisasional yang memberikan kontribusi terendah adalah Normative Commitment. Normative Commitment dicerminkan dari tetap tinggal di perusahaan karena suatu kewajiban, memiliki kepedulian terhadap masa depan perusahaan, dan tidak akan meninggalkan perusahaan, walaupun perusahaan dalam keadaan baik maupun buruk. Setiap karyawan yang bekerja di suatu perusahaan atau organisasi, harus mempunyai komitmen dalam bekerja karena apabila suatu perusahaan karyawannya tidak mempunyai suatu komitmen dalam bekerja, maka tujuan dari perusahaan atau organisasi tersebut tidak akan tercapai. Komitmen pada setiap karyawan sangat penting karena dengan suatu komitmen seorang karyawan dapat menjadi lebih bertanggung jawab terhadap pekerjaannya dibanding dengan karyawan yang tidak mempunyai komitmen. Biasanya karyawan yang memiliki suatu komitmen, akan bekerja secara optimal sehingga dapat mencurahkan perhatian, pikiran, tenaga dan waktunya untuk pekerjaanya, sehingga apa yang sudah dikerjakannya sesuai dengan yang diharapkan oleh perusahaan.

d. Kinerja

Kinerja pegawai dibentuk oleh kuantitas, kualitas dan ketepatan waktu. Hal utama yang dapat meningkatkan kinerja pegawai adalah kualitas. Kualitas dicerminkan dari selalu mengerjakan tugas dengan teliti dan hasil pekerjaan sesuai dengan mutu yang ditetapkan perusahaan. Sebagaimana konsepsi Timpe (2002) bahwa kinerja adalah tingkat prestasi 
seseorang atau karyawan dalam suatu organisasi atau perusahaan yang dapat meningkatkan produktivitas. Kualitas kerja berarti pegawai harus memiliki keterampilan, pengetahuan, dan niat baik untuk bekerja dengan berkualitas, rapi, bersih, dan teliti. Sedangkan indikator kinerja karyawan yang memberikan kontribusi terendah adalah ketepatan waktu, yang dicerminkan dari dapat mengerjakan tugas sesuai dengan waktu yang ditetapkan perusahaan dan waktu menyelesaikan pekerjaan meningkat dari periode sebelumnya.

\section{Pengaruh Pengembangan Sumber Daya Manusia terhadap Kinerja karyawan}

Pengembangan sumber daya manusia dilakukan agar dapat memberikan hasil sesuai dengan tujuan dan sasaran perusahaan dengan standar kinerja yang telah ditetapkan. Pengembangan sumber daya manusia direspon paling tinggi yang dapat meningkatkan kinerja karyawan yaitu indikator pelatihan. Pelatihan dicerminkan dari pelatihan-pelatihan yang pernah diikuti sudah sesuai dengan kebutuhan jabatan saat ini dan Pelatihanpelatihan yang diikuti bisa meningkatkan ketrampilan dalam pengambilan keputusan. Kinerja karyawan tergambarkan oleh kuantitas (hasil pekerjaan selesai sesuai dengan target yang telah ditetapkan dan bersedia lembur kerja jika pekerjaan belum terselesaikan), kualitas (Selalu mengerjakan tugas dengan teliti dan Hasil pekerjaan sesuai dengan mutu yang ditetapkan perusahaan), ketepatan waktu (dapat mengerjakan tugas sesuai dengan waktu yang ditetapkan perusahaan dan waktu menyelesaikan pekerjaan meningkat dari periode sebelumnya). Pengembangan sumber daya manusia lebih ditekankan pada peningkatan pengetahuan untuk melakukan pekerjaan pada masa yang akan datang, yang dilakukan melalui pendekatan yang terintegrasi dengan kegiatan lain untuk mengubah perilaku kerja. Sebagaimana konsepsi Mondy dan Noe (2006:270) yang menyatakan bahwa pengembangan sumber daya manusia adalah suatu usaha yang terencana dan berkelanjutan yang dilakukan oleh organisasi dalam meningkatkan kompetensi pegawai dan kinerja organisasi melalui programprogram pelatihan, pendidikan, dan pengembangan.

Apabila pengembangan sumber
daya manusia dilaksanakan secara sistematis, dapat memaksimalkan potensi karyawan di dalam organisasi, mencurahkan waktu, biaya, dan pemikiran untuk meningkatkan kompetensi penting yang dimiliki oleh para karyawan, hal tersebut dapat meningkatkan keahliannya serta memperlihatkan bahwa karyawan tersebut berharga bagi organisasi, sehingga berdampak pada peningkatan kinerja organisasi. Hal ini menunjukkan bahwa pengembangan sumber daya manusia mempunyai konsep untuk pengembangan diri, program pelatihan serta kemajuan karir untuk memenuhi kebutuhan organisasi akan keahlian di masa yang akan datang. Pengembangan sumber daya manusia juga memberikan kewenangan pada karyawan, memberi kesempatan pada individu untuk mengontrol karir karyawan serta untuk mengembangkan pola kehidupannya, sehingga dapat meningkatkan kinerja karyawan PT. HM. Sampoerna, Tbk Sukorejo Pandaan.

Pengembangan sumber daya manusia di PT. HM. Sampoerna, Tbk Sukorejo Pandaan telah diterapkan dengan baik sehingga terbukti mampu meningkatkan kinerja karyawan. Program pelatihan dan pengembangan telah dilaksanakan sesuai dengan kebutuhan karyawan dan kepentingan karyawan, kesempatan pengembangan karir bagi karyawan telah diberikan secara adil, penilaian atau evaluasi kinerja telah dilakukan dengan tepat. Kondisi tersebut telah mendorong peningkatan kinerja karyawan yang ditunjukkan dengan adanya penyelesaian jumlah pekerjaan/tugas sesuai harapan perusahaan (penyelesaian 
tugas secara kuantitas), serta terciptanya suasana kerja yang kondusif. Selain itu, penempatan karyawan sesuai dengan kemampuannya mampu mendorong karyawan dapat menyelesaikan pekerjaan/tugasnya. Adanya kesempatan berkembang membuat karyawan senantiasa memiliki motivasi diri (keuletan, kerja keras, integritas, niat, empati, dan ketegasan) dalam melaksanakan pekerjaan. Kondisi-kondisi tersebut mencerminkan bahwa karyawan mampu berkinerja baik. Hasil penelitian ini konsisten dengan penelitian yang dilakukan Kurniawan (2010) yang menyatakan bahwa pengembangan sumber daya manusia berpengaruh terhadap kinerja. Dalam penelitian Limgiani (2013), juga membuktikan bahwa pengembangan sumber daya manusia berpengaruh terhadap kinerja. Hasil penelitian ini juga konsisten dengan Wicaksono (2016) yang menyatakan bahwa pengembangan sumber daya manusia berpengaruh terhadap kinerja, demikian juga hasil penelitian Sukarjati et al. (2016) membuktikan bahwa pengembangan sumber daya manusia berpengaruh positif dan signifikan pada kinerja.

\section{Pengaruh Kompensasi terhadap Kinerja karyawan}

Kompensasi yang memadai dan sesuai dengan harapan karyawan, maka karyawan dapat menjadi terpacu untuk memberikan kontribusi yang terbaik pada perusahaan. Sebaliknya jika karyawan merasa tidak puas dengan kompensasi yang diterimanya maka ia akan merasa malas dalam melaksanakan pekerjaannya, hal ini tentu berpengaruh terhadap kinerja karyawan. Kompensasi direspon paling tinggi yang dapat meningkatkan kinerja karyawan yaitu indikator kompensasi finansial dan non finansial. kompensasi finansial dicerminkan dari kesesuaian gaji dengan yang diharapkan, pimpinan memberikan bonus bagi karyawan yang berprestasi dan perusahaan memberikan tunjangan dengan ketentuan perusahaan. Sedangkan kompensasi non finansial dicerminkan dari diberikan kesempatan untuk meningkatkan jenjang karir, mendapat penghargaaan (Reward) atas prestasi pekerjaan dan memperoleh fasilitas sesuai dengan jabatan dalam pekerjaan. Kinerja karyawan tergambarkan oleh kuantitas (hasil pekerjaan selesai sesuai dengan target yang telah ditetapkan dan bersedia lembur kerja jika pekerjaan belum terselesaikan), kualitas (selalu mengerjakan tugas dengan teliti dan hasil pekerjaan sesuai dengan mutu yang ditetapkan perusahaan), ketepatan waktu (dapat mengerjakan tugas sesuai dengan waktu yang ditetapkan perusahaan dan waktu menyelesaikan pekerjaan meningkat dari periode sebelumnya). Perusahaan yang menentukan tingkat upah dengan mempertimbangkan standar kehidupan normal akan memungkinkan karyawan bekerja dengan penuh semangat. Paket kompensasi dan manfaat perusahaan dirancang untuk memastikan daya saing PT. HM. Sampoerna, Tbk Sukorejo Pandaan di antara perusahaan terkemuka di Indonesia. Beberapa inisiatif telah dikembangkan dengan memperhatikan aspirasi dan masukan dari karyawan serta survei pasar untuk memastikan bahwa paket manfaat PT. HM. Sampoerna, Tbk Sukorejo Pandaan telah sesuai dengan kebutuhan karyawan sekaligus menjaga daya saing.

Dalam menentukan besarnya kompensasi terutama gaji terhadap karyawan, maka PT. HM. Sampoerna, Tbk Sukorejo Pandaan sudah memberitahukan terlebih dahulu kepada karyawan sebelum karyawan diterima bekerja di perusahaan, sehingga karyawan mengetahui secara terinci apa saja yang harus dilakukan dan berapa yang akan diterima karyawan dari hasil kerjanya. Gaji yang ditetapkan oleh PT. HM. Sampoerna, Tbk Sukorejo Pandaan terhadap karyawannya bervariasi. Hal ini disebabkan dalam menetapkan gaji kepada karyawan pihak perusahaan mempertimbangkan tingkat pendidikan, 
masa kerja, posisi/kedudukan karyawan serta kemampuan dan keahlian karyawan. Hasil penelitian ini konsisten dengan penelitian Lestariningsih et al. (2012) yang menyatakan bahwa kompensasi berpengaruh terhadap kinerja, demikian juga hasil penelitain Supiyanto (2015) yang menyatakan bahwa kompensasi berpengaruh terhadap kinerja.

Kebijakan kompensasi atau balas jasa yang ditentukan perusahaan dapat mempengaruhi perilaku kerja karyawan yang pada akhirnya akan berdampak pada semangat kerja yang bersangkutan. Bagi karyawan kompensasi yang diterimnaya akan dipergunakan untuk memenuhi kebutuhan-kebutuhannya beserta keluarganya. Selain itu, besarnya kompensasi yang diterimanya mencerminkan status, pengakuan dan tingkat pemenuhan kebutuhan yang dinikmati oleh karyawan bersama keluarganya. Jika kompensasi yang diterima karyawan semakin besar berarti jabatannya semakin tinggi, statusnya semakin tinggi dan pemenuhan kebutuhan yang dinikmatinya semakin banyak pula. Sebaliknya, bagi perusahaan kompensasi merupakan pengeluaran dan biaya bagi perusahaan. Perusahaan mengharapkan agar kompensasi yang dikeluarkan memperoleh imbalan hasil kerja yang lebih besar dari karyawan. Jadi nilai hasil kerja karyawan harus lebih besar dari kompensasi yang dibayar perusahaan, supaya perusahaan tersebut mendapatkan laba dan kontinuitas perusahaan terjamin.

Selain kompensasi finansial yang diharapkan karyawan, maka kompensasi non finansial juga memegang peranan yang cukup penting terhadap semangat kerja. Kompensasi non finansial lebih berorientasi pada kebutuhan karyawan untuk memperoleh pengakuan, berprestasi dan lebih bertanggung jawab. Kompensasi non finansial dapat memempengaruhi semangat kerja karena berkaitan dengan keinginan karyawan di tempat kerja. Program-program kompensasi juga penting bagi perusahaan karena mencerminkan upaya organisasi untuk mempertahankan sumberdaya manusia. Di samping itu, kompensasi sering merupakan komponenkomponen biaya yang paling besar dan penting. Bila kebijakan kompensasi tidak diadministrasikan secara tepat, maka perusahaan bias kehilangan karyawannya yang baik dan harus mengeluarkannya biaya untuk menarik, menyeleksi, melatih dan mengembangkan penggantinya. Bahkan bila karyawan memutuskan untuk tidak keluar, karyawan mungkin menjadi tidak puas terhadap perusahaan dan akan menurunkan hasil kerja karyawan.

Hasil penelitian ini mendukung pendapat Moekijat (2006:56-57) menyebutkan salah satu faktor yang digunakan dalam memelihara stabilitas moral atau semangat kerja adalah insentifinsentif yang berupa uang. Dari paparan di atas dapat disimpulkan bahwa kompensasi dapat berperan mendorong dan memelihara stabilitas semangat (moral) kerja. Di samping itu menurut Siagian (2009:114), cara-cara yang paling tepat untuk meningkatkan semangat kerja dan kegairahan kerja antara lain: gaji yang cukup, memperhatikan kebutuhan rohani, sesekali perlu mendapatkan suasana santai, harga diri perlu mendapat perhatian, menempatkan karyawan pada posisi yang tepat, memberikan kesempatan untuk maju, perasaan aman untuk masa depan perlu diperhatikan, usahakan agar karyawan mempunyai loyalitas, sesekali karyawan perlu diajak berunding, pemberian insentif yang menyenangkan, dan fasilitas yang menyenangkan.

\section{Pengaruh Komitmen Organisasional terhadap Kinerja karyawan}

Komitmen organisasional merupakan orientasi yang dimiliki karyawan terhadap perusahaan yang dapat menghubungkan identitas seseorang pada perusahaan. Komitmen organisasional penting karena memiliki hubungan yang erat dengan kinerja karyawan. Komitmen organisasional direspon paling tinggi yang dapat meningkatkan kinerja karyawan 
yaitu indikator affective commitment. Affective Commitment dicerminkan dari senang bisa menghabiskan sisa karir di perusahaan, bangga menjadi anggota dari perusahaan dan mempunyai keinginan untuk tetap tinggal di perusahaan. Kinerja karyawan tergambarkan oleh kuantitas (hasil pekerjaan selesai sesuai dengan target yang telah ditetapkan dan bersedia lembur kerja jika pekerjaan belum terselesaikan), kualitas (selalu mengerjakan tugas dengan teliti dan hasil pekerjaan sesuai dengan mutu yang ditetapkan perusahaan), ketepatan waktu (dapat mengerjakan tugas sesuai dengan waktu yang ditetapkan perusahaan dan waktu menyelesaikan pekerjaan meningkat dari periode sebelumnya). Karyawan yang memiliki komitmen yang tinggi terhadap perusahaan cenderung akan lebih baik kinerjanya dan juga akan lebih lama bertahan di perusahaan. Menyadari pentingnya komitmen organisasional, maka komitmen karyawan terhadap organisasi perlu ditumbuh kembangkan. Dukungan organisasi terhadap peningkatan komitmen organisasi turut mempengaruhi sikap dan perilaku positif karyawan terhadap organisasi, yang berujung pada kepuasan atau ketidakpuasan karyawan dalam bekerja. Dukungan organisasi dapat melalui perlakuan-perlakuan positif terhadap karyawan, seperti penghargaan, perlakuan pimpinan, karakteristik pekerjaan atau suasana kerja. Sebagaimana konsepsi Newstroom dalam Sopiah (2008:156) menyatakan bahwa secara konseptual, komitmen organisasional ditandai oleh tiga hal : (1) Adanya rasa percaya yang kuat dan penerimaan seseorang terhadap tujuan dan nilai-nilai organisasi, (2) Adanya keinginan seseorang untuk melakukan usaha secara sungguh-sungguh demi organisasi, (3) adanya hasrat yang kuat untuk mempertahankan keanggotaan dalam suatu organisasi.

Keberhasilan dari organisasi tidak terlepas dari peran karyawan yang terlibat di dalamnya, karena dengan adanya komitmen yang baik maka tingkat produktivitas dan kualitas kerja akan meningkat, dan pada akhirnya akan menunjang tercapainya tujuan organisasi. Karyawan yang memiliki komitmen, memiliki kesetiaan yang tinggi, maka karyawan akan bekerja dengan seoptimal mungkin demi tercapainya kinerja yang baik. Selain itu, perusahaan atau organisasi harus mampu membangun kepercayaan, dimana kepercayaan merupakan suatu cara untuk menciptakan komitmen. Kepercayaan dari karyawan tidak akan diperoleh apabila karyawan hanya diperlakukan sebagai salah satu faktor produksi, bukan sebagai asset utama perusahaan. Selain itu, karyawan tidak merasa sebagai bagian dari organisasi apabila tidak dihargai oleh organisasi.

Komitmen organisasional merupakan suatu bentuk kesetiaan terhadap organisasi. Kesetiaan itu ditandai dengan adanya rasa percaya, rasa menerima, serta adanya keinginan untuk mempertahankan kedudukan yang semata-mata dilakukan untuk mencapai tujuan yang telah ditetapkan sebelumnya. Tujuan yang telah ditetapkan dalam hal ini tidak hanya untuk kepentingan lembaga saja, melainkan juga untuk kepentingan orang-orang yang bergabung dalam organisasi tersebut, diantaranya adalah karyawan. Hasil penelitian ini sejalan dengan penelitian Lestariningsih et al. (2012) yang menyatakan bahwa komitmen organisasional berpengaruh terhadap kinerja, demikian juga dengan hasil penelitian Limgiani (2013) yang membuktikan bahwa komitmen organiasional berpengaruh terhadap kinerja, hasil penelitian Supiyanto (2015) juga menyatakan bahwa komitmen organisasional berpengaruh terhadap prestasi kerja.

\section{KESIMPULAN DAN SARAN Kesimpulan}

1. Pengembangan sumber daya manusia dibentuk dari pelatihan, pendidikan dan 
pengembangan. Hal utama yang dapat mendorong pengembangan sumber daya manusia adalah pelatihan. Pelatihan dicerminkan dari pelatihan-pelatihan yang pernah diikuti sudah sesuai dengan kebutuhan jabatan saat ini dan pelatihan-pelatihan yang diikuti bisa meningkatkan ketrampilan dalam pengambilan keputusan. Kompensasi dibentuk oleh kompensasi dibentuk oleh kompensasi finansial dan kompensasi non finansial. Kompensasi finansial dan kompensasi non finansial penting bagi karyawan, kompensasi finansial dicerminkan dari kesesuaian gaji dengan yang diharapkan, pimpinan memberikan bonus bagi karyawan yang berprestasi dan perusahaan memberikan tunjangan dengan ketentuan perusahaan. Sedangkan kompensasi non finansial dicerminkan dari diberikan kesempatan untuk meningkatkan jenjang karir, mendapat penghargaaan (Reward) atas prestasi pekerjaan dan memperoleh fasilitas sesuai dengan jabatan dalam pekerjaan. Komitmen organisasional terbentuk dari Affective Commitment, Continuance Commitment dan Normative Commitment. Hal utama yang dapat meningkatkan komitmen organisasional adalah Affective Commitment. Affective Commitment dicerminkan dari senang bisa menghabiskan sisa karir di perusahaan, bangga menjadi anggota dari perusahaan dan mempunyai keinginan untuk tetap tinggal di perusahaan. Kinerja karyawan dibentuk dari kuantitas, kualitas dan ketepatan waktu. Hal utama yang dapat meningkatkan kinerja karyawan adalah kualitas pekerjaan. Kualitas dicerminkan dari selalu mengerjakan tugas dengan teliti dan hasil pekerjaan sesuai dengan mutu yang ditetapkan perusahaan.

2. Pengembangan sumber daya manusia, Kompensasi dan komitmen organisasional berpengaruh terhadap kinerja karyawan PT. HM. Sampoerna,
Tbk Sukorejo Pandaan, yang berarti bahwa pengembangan sumber daya manusia yang dilaksanakan dengan baik, didukung dengan adanya kompensasi yang memadai, dan karyawan yang berkomitmen organisasional tinggi dapat meningkatkan kinerja karyawan. Apabila pengembangan sumber daya manusia dilaksanakan secara sistematis, dapat memaksimalkan potensi karyawan di dalam organisasi, mencurahkan waktu, biaya, dan pemikiran untuk meningkatkan kompetensi penting yang dimiliki oleh para karyawan, hal tersebut dapat meningkatkan keahliannya serta memperlihatkan bahwa karyawan tersebut berharga bagi organisasi, sehingga berdampak pada peningkatan kinerja organisasi. Kompensasi yang memadai dan sesuai dengan harapan karyawan, maka karyawan dapat menjadi terpacu untuk memberikan kontribusi yang terbaik pada perusahaan. Karyawan yang memiliki komitmen yang tinggi terhadap perusahaan cenderung akan lebih baik kinerjanya dan juga akan lebih lama bertahan di perusahaan.

3. Pengembangan sumber daya manusia berpengaruh lebih dominan dibandingkan kompensasi dan komitmen organisasional terhadap kinerja karyawan PT. HM. Sampoerna, Tbk Sukorejo Pandaan. Hal ini menunjukkan bahwa hal utama yang dipertimbangkan untuk meningkatkan kinerja karyawan PT. HM. Sampoerna, Tbk Sukorejo Pandaan yaitu pengembangan sumber daya manusia. Pengembangan sumber daya manusia direspon paling tinggi yang dapat meningkatkan kinerja karyawan yaitu indikator pelatihan. Pelatihan dicerminkan dari pelatihan-pelatihan yang pernah diikuti sudah sesuai dengan kebutuhan jabatan saat ini dan Pelatihan-pelatihan yang diikuti bisa meningkatkan ketrampilan dalam 
pengambilan keputusan. Kinerja karyawan tergambarkan oleh kuantitas (hasil pekerjaan selesai sesuai dengan target yang telah ditetapkan dan bersedia lembur kerja jika pekerjaan belum terselesaikan), kualitas (Selalu mengerjakan tugas dengan teliti dan Hasil pekerjaan sesuai dengan mutu yang ditetapkan perusahaan), ketepatan waktu (dapat mengerjakan tugas sesuai dengan waktu yang ditetapkan perusahaan dan waktu menyelesaikan pekerjaan meningkat dari periode sebelumnya). Pengembangan sumber daya manusia lebih ditekankan pada peningkatan pengetahuan untuk melakukan pekerjaan pada masa yang akan datang, yang dilakukan melalui pendekatan yang terintegrasi dengan kegiatan lain untuk mengubah perilaku kerja.

\section{Saran-saran}

1. Sebaiknya perusahaan dalam pengembangan sumber daya manusia mempertahankan pelatihan dan pendidikan yang telah dilaksanakan oleh perusahaan dan meningkatkan pengembangan bagi karyawan agar karyawan lebih terampil dalam menyelesaikan pekerjaan.

2. Pada dasarnya kompensasi sudah sesuai dengan ketentuan yang berlaku, untuk itu sebaiknya perusahaan tetap mempertahankan dan meningkatkan kompensasi, agar semangat kerja karyawan dapat semakin meningkat, hal ini mengingat kompensasi masih menjadi alasan utama bagi seseorang untuk bekerja, yaitu dengan cara perusahaan mengikuti perkembangan kenaikan UMR dan memberikan kenaikan bonus tiap tahun. Dengan kompensasi yang diterimanya terutama kompensasi langsung akan dipergunakan karyawan untuk memenuhi kebutuhan hidupnya. Oleh karena itu untuk memacu karyawan agar dapat bekerja dengan lebih baik, maka pihak perusahaan harus dapat memanfaatkan faktor kompensasi yang diberikan kepada karyawan agar karyawan terdorong untuk bekerja dengan lebih baik dan memberikan kontribusi terbaik bagi perusahaan.

3. Sebaiknya perusahaan mempertahankan komitemen organisasional yang sudah ada dengan menciptakan suasana kerja yang kondusif di perusahaan, sehingga karyawan merasa nyaman dan senang bekerja di perusahaan.

4. Agar kinerja karyawan dapat meningkat, sebaiknya pihak perusahaan mempertahankan kualitas hasil kerja karyawan dan meningkatkan kuantitas dan ketepatan waktu dalam menyelesaikan pekerjaan dengan cara mau mendengarkan ide-ide dan masukan dari karyawan.

5. Bagi peneliti yang akan datang, guna pengembangan ilmu serta teori Manajemen Sumber Daya Manusia yang berkaitan dengan Kinerja, di mana Kinerja dipengaruhi pengembangan sumber daya manusia, kompensasi dan komitmen organisasional. Faktor-faktor lain selain pengembangan sumber daya manusia, kompensasi dan komitmen organisasional yang belum dikaji dalam penelitian ini menjadi pertimbangan untuk dilakukan analisis pada penelitian selanjutnya, misalnya kemampuan, disiplin kerja, dan kepuasan kerja.

\section{DAFTAR PUSTAKA}

Dharma, Agus. 2005. Manajemen Supervisi. Jakarta: PT. RajaGrafindo Persada.

Handoko, T. Hani. 2008. Manajemen Personalia dan Sumber Daya Manusia. Edisi Kedua. Yogyakarta: BPFE.

Hasibuan, Malayu S. P. 2008. Organisasi dan Motivasi: Dasar Peningkatan Produktivitas. Jakarta: Bumi Aksara.

Kurniawan, Agung Widhi. 2010. Pengaruh Kepemimpinan Dan Pengembangan Sumber Daya Manusia Terhadap Kepuasan Kerja, Motivasi Kerja, 
Dan Kinerja Bank Sulselbar. Tesis. Universitas Negeri Makassar.

Lestariningsih, Marsudi, Firdaus M Sitohang dan Triyonowati. 2012. Pengaruh Kompensasi, Komitmen Karyawan, Lingkungan dan Iklim Kerja Terhadap Kinerja Karyawan UD Sinar Abadi Di Sidoarjo. Jurnal Akuntansi, Manajemen Bisnis dan Sektor Publik (JAMBSP). Vol. 8 No. 3: $315-337$.

Limgiani. 2013. Analisis Pengaruh Pengembangan Sumber Daya Manusia, Komitmen Organisasional Dan Motivasi Kerja, Terhadap Loyalitas Dan Kinerja Tenaga Kependidikan Sekolah Tinggi Ilmu Kesehatan Di Malang Raya. Disertasi. Universitas Merdeka Malang.

Mangkunegara, Anwar Prabu. 2009. Manajemen Sumber Daya Manusia Perusahaan. Bandung: Remaja Rosadakarya.

Moekijat. 2006. Latihan dan pengembangan Sumber daya Manusia. Cetakan Kelima. Mandar Maju. Bandung.

Mondy, R. Wayne dan Noe M. Robert. 2006, Human Resource Management, Allyn and Bacon.

Rivai, V. 2009. Manajemen Sumber Daya Manusia untuk Perusahaan.. Jakarta: PT. Raja Grafindo Persada

Sanusi, Anwar. 2014. Metodologi Penelitian Bisnis. Cetakan Kelima. Penerbit Salemba Empat. Jakarta.

Siagian, Sondang P. 2009. Manajemen Sumber Daya Manusia. Bumi Aksara. Jakarta.

Simamora, Henry. 2006. Manajemen Sumber Daya Manusia. Yogyakarta: STIE YKDI

Sopiah. 2008. Perilaku Organisasional. Yogyakarta : Penerbit Andi.
Sukarjati, Endang, Maria Magdalena Minarsih dan Moh. Mukeri Warso. 2016. Pengaruh Kepemimpinan, Pengembangan Sumber Daya Manusia dan Kepuasan Kerja Terhadap Kinerja Pegawai Kantor Dinas Pengelolaan Keuangan Dan Aset Daerah Kota Semarang. Journal of Management Vol.02 No.02: 1-14

Sulistyani, A.T \& Rosidah. 2003. Manajemen Sumber Daya Manusia: Konsep, Teori dan Pengembangan dalam Konteks Organisasi Publik. Yogyakarta: Graha Ilmu.

Sunarto. 2005. Manajemen Karyawan. Yogyakarta: AMUS.

Supiyanto, Yudi. 2015. Pengaruh Kompensasi, Kompetensi Dan Komitmen Organisasional Terhadap Kepuasan Kerja dan Kinerja Karyawan Koperasi. Prosiding Seminar Nasional.

Swanson, Ricahard. A., dan Elwood F. Holton III. 2006. Foundations of Human Resource Development. San Francisco: Bernett-Koehler Publishers, Inc.

Taylor, Shelley E., Letitia Anne Peplau dan David O. Sears. 2009. Psikologi Sosial. Jakarta: Kencana.

Timpe, Dale. 2002. Seri Manajemen Sumber Daya Manusia Kinerja. Cetakan Kelima. Jakarta: PT Elex Media Komputindo.

Wibowo. 2011. Manajemen Kinerja. Jakarta Utara: Rajawali Pers.

Wicaksono, Yosep Satrio. 2016. Pengaruh Pelatihan dan Pengembangan Sumber Daya Manusia Dalam Rangka Meningkatkan Semangat Kerja Dan Kinerja Karyawan (Studi di SKM Unit V PT. Gudang Garam,Tbk Kediri). Jurnal Bisnis dan Manajemen. Vol. 3 No.1: 31-39 